\title{
Nanomedicine and cancer immunotherapy: focus on indoleamine 2,3-dioxygenase inhibitors
}

\author{
This article was published in the following Dove Press journal: \\ OncoTargets and Therapy \\ 21 January 2017 \\ Number of times this article has been viewed
}

\author{
Bilal Zulfiqar' \\ Amnah Mahroo' \\ Kaenat Nasir \\ Rai Khalid Farooq ${ }^{2}$ \\ Nasir Jalal ${ }^{3}$ \\ Muhammad Usman Rashid ${ }^{4}$ \\ Kashif Asghar ${ }^{1,4}$ \\ 'Healthcare Biotechnology \\ Department, Atta-ur-Rahman School \\ of Applied Biosciences (ASAB), \\ National University of Sciences \\ and Technology (NUST), Islamabad, \\ ${ }^{2}$ Department of Physiology, Army \\ Medical College, National University \\ of Medical Sciences, Rawalpindi, \\ Pakistan; ${ }^{3}$ Department of Molecular \\ and Cellular Pharmacology, Health \\ Sciences Platform, Tianjin University, \\ Tianjin, People's Republic of China; \\ ${ }^{4}$ Basic Sciences Research, Shaukat \\ Khanum Memorial Cancer Hospital \\ and Research Centre (SKMCH\&RC), \\ Lahore, Pakistan
}

\begin{abstract}
Nanomedicine application in cancer immunotherapy is currently one of the most challenging areas in cancer therapeutic intervention. Innovative solutions have been provided by nanotechnology to deliver cytotoxic agents to the cancer cells partially affecting the healthy cells of the body during the process. Nanoparticle-based drug delivery is an emerging approach to stimulate the immune responses against cancer. The inhibition of indoleamine 2,3-dioxygenase (IDO) is a pivotal area of research in cancer immunotherapy. IDO is a hemecontaining immunosuppressive enzyme, which is responsible for the degradation of tryptophan while increasing the concentration of kynurenine metabolites. Various preclinical studies showed that IDO inhibition in certain diseases may result in significant therapeutic effects. Here, we provide a review of the natural and synthetic inhibitors of IDO. These inhibitors are classified according to their source, inhibitory concentrations, the chemical structure, and the mechanism of action. Tumor-targeted chemotherapy is an advanced technique and has more advantages as compared to the conventional chemotherapy. Search for more efficient and less toxic nanoparticles in conjunction with compounds to inhibit IDO is still an area of interest for several research groups worldwide, especially revealing to be an extensive and a promising area in cancer therapeutic innovations.
\end{abstract}

Keywords: indoleamine 2,3-dioxygenase, natural inhibitors of IDO, synthetic inhibitors of IDO, nanomedicine, cancer therapeutics

\section{Introduction}

Medicine has evolved dramatically in recent years. New strategies have emerged for the diagnosis and treatment of various diseases, leading to a better prognosis and improved quality of life in patients. Within this new environment that combines technology and medicine, it seems that the next rung on the ladder of technological advances is primarily focused on nanomedicine, especially in the area of cancer biology. In conventional chemotherapy, drugs generally exhibit high toxicity for both cancer and healthy cells. ${ }^{1}$ Nanomedicine offers the possibility of a direct effect of drugs on diseased cells without harming the healthy cells in the body, ${ }^{2}$ preventing the high toxicity associated with chemotherapy. This leads to a therapeutic advantage that only affects the tumor and preserves the structure and function of the healthy tissue.

Nanoparticles are gradually being used as a carrier for delivering molecular drugs to the sites of tumor growth. Nanoparticles not only increase the circulation time of the molecular cargo but also protects it from biodegradation. ${ }^{3}$ Liposomes, ${ }^{4}$ hydrogels, ${ }^{5}$ nanofibers, ${ }^{6}$ metallic nanoparticles ${ }^{7}$ and nanodiamonds ${ }^{8}$ are examples of nanomaterials that have been widely tested as transporters for specific drugs for the treatment of cancers. The first polymeric vector for small interfering RNA delivery entered a phase I trial in 2008. It was termed as CALAA-01 and was prepared using 
cyclodextrin-polyethylene glycol-transferrin (cyclodextrinPEG-Tf) nanoparticle formulation. ${ }^{9}$ One method currently in use is conjugating an antibody with a radioactive isotope to permit imaging by the emission of photons or beta radiation preventing tumor metastasis. ${ }^{10}$ Another possible method for treatment using the noninvasive approach for tumor removal is nanoshell-assisted photothermal therapy. ${ }^{11}$ Nanoshells are nanoparticles comprising silica, coated with a thin layer of metal, usually gold. These nanoparticles have a sharp gel-liquid phase transition that is used for rapid drug release at hyperthermic temperatures. ${ }^{12}$ Conjugated PEGylated silicacore gold nanoshells that precisely target the cancer cells in the peritoneal cavity. ${ }^{13}$

Tumor-targeted chemotherapy is an advanced technique and has more benefits as compared to the conventional chemotherapy. ${ }^{2,14}$ Advancement in the nanofabrication technologies now makes it possible to use the nanostructured materials in drug delivery. ${ }^{15}$ Polymeric micelles are used as transporters for delivery of drugs and nucleic acids. ${ }^{16}$ The biodistribution of nanoparticles is dependent on the size and surface properties. Therefore, the size of nanoparticles must be $>7 \mathrm{~nm}$ but $<100 \mathrm{~nm}$ in order to protect their elimination from the body. ${ }^{3,16,17}$ These nanoparticles can be modified by different means to enhance their specificity for different types of tumors.

It has been shown that for unmodified nanoparticles, the dominant uptake pathway is macrophagocytosis, whereas for the nanoparticles conjugated with interleukin (IL)-13 peptide, the uptake is mediated by clathrin-dependent endocytosis. ${ }^{18}$ In the mid-1990s Food and Drug Administration (FDA) adopted a liposomal formulation of doxorubicin, Doxil ${ }^{\circledR}$; this formulation exhibited decreased cardiotoxicity compared with doxorubicin ${ }^{19}$ for the treatment of ovarian cancer. Another example is the drug Abraxane ${ }^{\circledR}$ approved by the FDA in 2005 , formulated with a nanoparticle containing albumin and paclitaxel indicated for the treatment of various cancers. ${ }^{20,21}$ Nanoparticles have also been used to formulate vaccines showing promising potential in the cancer immunotherapy. It has been demonstrated that antigen-presenting cells actively take in antigen-loaded nanocarriers by initiating an immunostimulatory cascade, which can work against the cancer cell. ${ }^{22}$ Moreover, nanomaterials have been used as auxiliary agents for obtaining diagnostic images of better quality by making use of imaging methods, such as computed tomography or magnetic resonance imaging. ${ }^{22}$ This is achieved by encapsulating nanoparticles in contrast to media such as gadolinium or superparamagnetic iron oxide, so that the location of tumors or metastases can be determined more accurately, staging the disease and suggesting the most appropriate treatment plan. ${ }^{23}$ Recently, nanorobotics has been reconciled with nanomedicine by combining minimally invasive diagnosis with miniaturized robotics in conjunction with computer-assisted surgery. This approach has been used to target benign tumors in cancer surgery. ${ }^{24-26}$

Nanoparticles possess immunostimulatory effect ${ }^{27}$ as the biomolecules encapsulated within or attached to nanoparticles are known to elicit enhanced T- and B-cell responses as compared to the biomolecules delivered in a soluble form. ${ }^{28}$ Gold nanoparticles are used preferentially for drug delivering, diagnosis and treatment of cancer. ${ }^{29}$

The implementation of nanomedicine in the treatment and diagnosis of cancer has acquired great value and drugs combined with nanoparticles are already in various stages of preclinical and clinical trials for the treatment of breast, lung, melanoma, pancreatic and gastroesophageal cancers $^{30}$ (Tables 1 and 2).

Novel therapies utilizing nanomedicine can result in superior treatments as compared to the current regimens. The goal to achieve increased efficacy and reduced toxicity has been achieved by overcoming the drug delivery challenges using nanomedicine to detect and treat pancreatic ductal adenocarcinoma, ${ }^{31}$ colorectal cancer $(\mathrm{CRC}),{ }^{32}$ melanoma $^{33}$ and cervical cancer. ${ }^{34}$

The inhibition of indoleamine 2,3-dioxygenase (IDO) is a pivotal area of research in cancer immunotherapy. IDO is a heme-containing enzyme that catalyzes the oxidative cleavage of 2,3 double bond of indole ring. ${ }^{35}$ IDO has the ability to inhibit T-cell activation by tryptophan starvation, whereas T-cell survival and proliferation are regulated by $\mathrm{O}_{2}$ free radicals and kynurenine derivatives. ${ }^{36}$ IDO plays a crucial role in autoimmunity, ${ }^{36,37}$ infections $^{38}$ and malignancies. ${ }^{39}$ Overexpression of IDO has been reported in breast, ${ }^{40-42}$ thyroid, ${ }^{43}$ pancreatic, ${ }^{44,45}$ prostate,${ }^{46,47}$ lung,,${ }^{48,49}$ cervical $^{50}$ and ovarian $^{51}$ cancers.

It has been reported that IDO expression can be modulated by CD137/CD137L pathway against Ewing sarcoma cells; IL2 plays a role in IDO expression from tumor cells due to interferon gamma (IFN- $\gamma$ ) production by lymphocytes. ${ }^{52}$ $\mathrm{PI} 3 \mathrm{~K} \rightarrow \mathrm{AKT} \rightarrow$ nuclear factor kappa light chain enhancer of activated B-cell pathway is also involved with IDO expression through CD80/CD86 induction. ${ }^{53}$

It is known that there is a population of $\mathrm{CD}^{+} \mathrm{T}$ cells able to inhibit responses of cytotoxic $\mathrm{T}$ cells to specific antigens, which are referred to as T-regulatory cell (T-reg). The phenotype of this cell population is $\mathrm{CD}^{+} / \mathrm{CD}^{2} 5^{+}$ CTLA4 ${ }^{+} /$FoxP3. ${ }^{54}$ T-regs can be induced by immature 
Table I Nanotechnological carrier systems used for cancer treatments

\begin{tabular}{|c|c|c|c|}
\hline Indication & Nanotechnological system & Compounds (agents) & Status \\
\hline \multirow[t]{4}{*}{ Leukemia } & Liposome & Topotecan + amlodipine $e^{|2|}$ & Preclinical \\
\hline & & 6-Mercaptopurine + daunorubicin ${ }^{122}$ & \\
\hline & Transferrin-conjugated PEGylated liposome & Doxorubicin + verapamil ${ }^{123}$ & \\
\hline & $\begin{array}{l}\text { Folate-G5 poly-propyleneimine dendrimer } \\
\text { with ethylenediamine core }\end{array}$ & Methotrexate + all-trans-retinoic acid ${ }^{124}$ & \\
\hline \multirow[t]{3}{*}{ Breast cancer } & Liposome & Gemcitabine + tamoxifen ${ }^{125}$ & \\
\hline & & Ceramide + sorafenib ${ }^{126}$ & \\
\hline & HER2 conjugated-GMO-MNPs & Paclitaxel + rapamycin ${ }^{127}$ & \\
\hline \multirow[t]{2}{*}{ Prostate cancer } & HPMA-Gem-Dox & Gemcitabine + doxorubicin ${ }^{128}$ & \\
\hline & Aptamer-G4 PAMAM dendrimer conjugates & Unmethylated CpG-ONTs + doxorubicin ${ }^{129}$ & \\
\hline \multirow[t]{2}{*}{ Glioblastoma } & G5 PAMAM dendrimer & Antisense-miRNA2I + 5-fluorouracil ${ }^{130}$ & \\
\hline & RGDfK-G3 poly-lysine dendrimer & Doxorubicin + siRNA ${ }^{|3|}$ & \\
\hline Cervical cancer & Liposome & PD032590I + siMcll I32 & \\
\hline Lung cancer & Liposome & Doxorubicin + msurvivin T34A plasmid $d^{133}$ & \\
\hline Brain cancer & PEG-liposome & Topotecan + vincristine ${ }^{134}$ & \\
\hline Hepatocellular carcinoma & PLGA & Vincristine + verapamil ${ }^{135}$ & \\
\hline Advanced colorectal & Liposome (CPX-I) & Irinotecan + floxuridine $e^{136}$ & Phase II \\
\hline cancer & Liposome (CPX-35I) & Cytarabine + daunorubicin ${ }^{137}$ & \\
\hline
\end{tabular}

Abbreviations: GMO, glycerol monooleate; HER2, human epidermal growth factor receptor 2; HPMA, N-(2-hydroxypropyl)methacrylamide; miRNA, microRNA; MNPs, magnetic nanoparticles; ONTs, oligonucleotides; PAMAM, polyamidoamine; PEG, polyethylene glycol; PLGA, poly lactic-co-glycolic acid; siRNA, small interfering RNA.

dendritic cell (DC) that accumulates at the tumor microenvironment. Ipilimumab, an anti-CTLA-4 antibody, has been approved for advanced melanoma patients. ${ }^{55}$ Two anti-PD-1 antibodies, pembrolizumab and nivolumab, have also been approved for patients with metastatic lung, breast, bladder and renal cancers. PD-1 is a protein of immunoglobulin superfamily that has a co-inhibition function for antigen presentation. It is expressed on the surface of T-lymphocytes activated, NKT cells, B-lymphocytes, monocytes and DCs. ${ }^{56}$ The interaction with their ligands PD-PD-L1 or L2 leads to the phosphorylation of PD-1 on tyrosine residues with the intracellular portion of the molecule, with subsequent recruitment of phosphatase SHP-2 and inhibition of signaling triggered by TCR. The increased expression of PD-L1 is common in the context of melanoma and appears to be induced by the neoplastic cells through unknown mechanisms. ${ }^{57}$

\section{IDO inhibitors as adjuvant therapy}

The mechanism of immune escape developed by a tumor cell may influence the success rate of a specific immunotherapeutic intervention. ${ }^{58}$ As IDO plays an important part in the immune escape scenario for a cancer cell, ${ }^{39}$ thus IDO inhibitors can act as an innovative and promising strategy for cancer therapy. ${ }^{59,60}$ To obtain better results, adjunct treatment is proposed in which the inhibitors should be administered concomitantly with cytotoxic chemotherapy agents. ${ }^{59-64}$ Several research groups are working in the search of new and more potent IDO inhibitors whether they are synthetic or endogenous. ${ }^{65}$ Structural basis of IDO provides different binding sites for substrates and cofactors, ${ }^{66}$ which allows for the development of competitive and noncompetitive inhibitors, ${ }^{67}$ leading to an increased number of possible inhibitory molecules to be used for targeted intervention.

Table 2 US FDA approved nanomedicines used for cancer treatments

\begin{tabular}{|c|c|c|c|c|c|c|}
\hline Drug & Class & Platform & $\begin{array}{l}\text { Drug carried } \\
\text { ratio }\end{array}$ & $\begin{array}{l}\text { Diameter } \\
(\mathrm{mm})\end{array}$ & $\begin{array}{l}\text { Dose } \\
\left(\mathrm{mg}^{2} / \mathrm{m}\right)\end{array}$ & References \\
\hline Doxorubicin & Liposome & Doxil $^{\circledR}$ & $10,000-15,000$ & 100 & $25-80$ & Gabizon et $\mathrm{al}^{16}$ and Hamilton et $\mathrm{al}^{138}$ \\
\hline Vincristine & Liposome & Marqibo & $\sim 10,000$ & 100 & $2.0-2.25$ & Bedikian et al $^{139}$ and Silverman and Deitcher ${ }^{140}$ \\
\hline Daunorubicin & Liposome & Daunoxome & $\sim 10,000$ & 50 & $10-190$ & Gill et $\mathrm{al}^{|4|}$ and Bellott et $\mathrm{al}^{142}$ \\
\hline Mertansine & $\begin{array}{l}\text { Antibody-drug } \\
\text { conjugates }\end{array}$ & $\begin{array}{l}\text { Trastuzumab } \\
\text { emtansine }\end{array}$ & $\leq 8$ & $\sim 10$ & $10-160$ & Lu et $\mathrm{al}^{143}$ \\
\hline Monomethyl auristan E & $\begin{array}{l}\text { Antibody-drug } \\
\text { conjugates }\end{array}$ & $\begin{array}{l}\text { Brentuximab } \\
\text { vedotin }\end{array}$ & $\leq 8$ & $\sim 10$ & $90-110$ & Younes et $\mathrm{al}^{144}$ and Bradley et $\mathrm{al}^{145}$ \\
\hline Paclitaxel & Protein carrier & Abraxane ${ }^{\circledR}$ & $>10,000$ & 130 & $150-300$ & Ando et $\mathrm{al}^{146}$ \\
\hline
\end{tabular}

Abbreviation: FDA, Food and Drug Administration. 
A clinical IDO inhibitor should ideally inhibit the local degradation of tryptophan in the tumor microenvironment and significantly in draining lymph nodes where the process of presentation of tumor antigens is most effective. ${ }^{66}$ It is most likely that novel potent IDO inhibitors will provide effective treatment when combined with other modalities of cancer therapy.

An enormous number of inhibitors have been tested for their pharmacologic activity against $\operatorname{IDO}^{68}$ (Figure 1). 1-Methyl tryptophan (1-MT) is the most important competitive inhibitor of IDO. ${ }^{69}$ Since the discovery of 1-MT in 1991, ${ }^{69}$ it has been widely studied because of its favorable pharmacokinetic activity, such as low protein binding, oral availability and low clearance. ${ }^{70}$ Currently, 1-MT is regarded as a classical IDO inhibitor in clinical research based on its exponential effectiveness in treating tumors. ${ }^{59}$ No case of toxicity has been reported against 1-MT till date except dehydration in a study carried out on mice model where this inhibitor was administered through drinking water. ${ }^{60}$ The efficacy of 1-MT is significantly enhanced when given in combination with powerful chemotherapeutic agents, such as paclitaxel, cisplatin, doxorubicin and cyclophosphamide. ${ }^{71}$ There are two stereoisomers of 1-MT: the D-isomer and L-isomer. ${ }^{72}$ Through in vitro testing by using different cell lines or cell-free assays, it has been revealed that the L-isomer exhibits the highest degree of efficacy against IDO, whereas it does not promote high level of T-cell proliferation in vivo as compared to the D-isomer. ${ }^{73}$ Beta-carboline derivatives

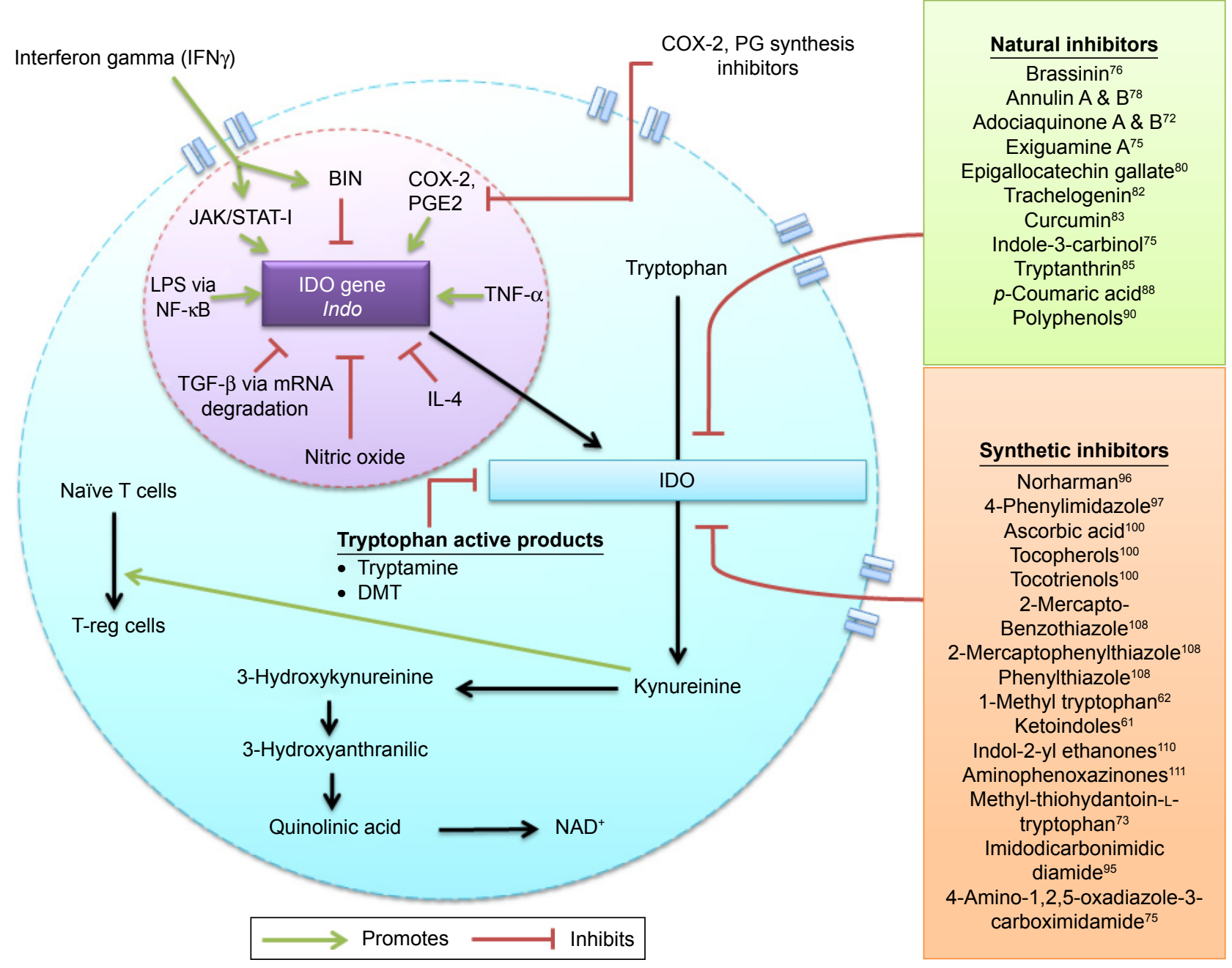

Figure I IDO pathway and inhibitors.

Notes: Tryptophan catabolism through the kynurenine pathway involves IDO an intracellular rate limiting enzyme and possible natural and synthetic inhibitors of this enzyme acting through various routes. IDO serves as an apoenzyme which is encoded by the Indo gene, this gene is upregulated by JAK/STAT signaling pathway induced by IFN- $\gamma$, cyclooxygenase-mediating prostaglandin E2, TNF- $\alpha$ and LPS regulated by NF- $\mathrm{KB}$. In contrast, it is downregulated by BIN gene, IL-4, nitric oxide and TGF- $\beta$ through mRNA degradation pathway. Apart from the natural and synthetic inhibitors certain tryptophan active products, such as tryptamine and DMT, also serve as modulators of this enzyme.

Abbreviations: COX-2, cyclooxygenase-2; DMT, N-dimethyltryptamine; IDO, indoleamine 2,3-dioxygenase; IFN- $\gamma$, interferon gamma; IL, interleukin; JAK, Janus kinase; LPS, lipopolysaccharides; mRNA, messenger RNA; NAD, aldehyde dehydrogenase; NF- $\mathrm{B}$, nuclear factor kappa light chain enhancer of activated B cells; PG, prostaglandin; PGE2, prostaglandin E2; STAT, signal transducers and activators of transcription; TGF- $\beta$, transforming growth factor $\beta$; TNF, tumor necrosis factor; T-reg, T-regulatory cells. 
comprise the class of noncompetitive inhibitors, ${ }^{48}$ which bind to the heme iron different to the active site where the substrate binds. A huge number of beta-carboline inhibitors have been developed, but their development has been restricted by the fact that these inhibitors behave as benzodiazepine ligands. ${ }^{37}$ Whether the IDO inhibitors are competitive or noncompetitive in nature; the basic mechanism of inhibition remains independent by the substitution of indole ring. ${ }^{62}$ However, now research is being carried out to find the potential inhibitors of IDO that use the mechanism of substitution of the indole ring.

\section{Natural inhibitors}

Recently, isolation of several natural products has revealed various potent IDO inhibitors. ${ }^{74,75}$ Chen et al investigated the relationship between anti-inflammatory properties of natural products and IDO activity. High concentration of numerous phytochemicals, possessing flavonoid chemical structure, has been reported in various medicinal plants, fruits and vegetables. For instance, curcumin, a natural IDO inhibitor, is an active ingredient of turmeric being used in treating cancer. Physiochemical properties and structures of natural inhibitors are described in Tables 2 and 3 and Figure 2.

\section{Brassinin}

Brassinin was first identified in the Chinese cabbage. ${ }^{76}$ It is a phytoalexin found in the cruciferous vegetables. The inhibition mechanism takes place when methyl dithiocarbamate chain, present in brassinin, substitutes the chain of amino acid in tryptophan. Thus, it presents a great potential to act as an anticancer agent. ${ }^{72}$ It is reported to be an active, moderately competitive IDO inhibitor and has shown an inhibitory constant $(\mathrm{K} i)$ value of $97.7 \mu \mathrm{M} .^{75,77}$

\section{Annulins and adociaquinones}

Andersen et al $^{94}$ demonstrated that a wide range of marine hydroids contain various natural products, which exhibit inhibitory activity $\left(\mathrm{IC}_{50}\right)$ against IDO. These products act in a noncompetitive manner. Annulins A and B, the pyranonaphthoquinones, are naturally obtained from the extracts of Garveia annulata, a marine hydroid. The annulin B has shown a $\mathrm{K} i$ of $0.12 \mu \mathrm{M}^{78}$ and are reported to be more active than 1-MT, whereas $\mathrm{K} i$ value for pyranonaphthoquinones is $0.07 \mu \mathrm{M} .{ }^{78}$ Crude extracts from Xestospongia sp. contain adociaquinones $\mathrm{A}$ and $\mathrm{B}$, which exhibit activity as IDO inhibitors. Adociaquinone $\mathrm{B}$ has shown most potent activity among other compounds with a $\mathrm{K} i$ of $25 \mathrm{nM} .^{72}$

\section{Exiguamine $\mathrm{A}$}

Another natural product exiguamine $\mathrm{A}$ has been revealed to cause the inhibition of IDO activity with a $\mathrm{K} i$ value of 0.04-0.21 $\mu \mathrm{M}$. However, the cellular mechanisms are still unknown. Nevertheless, this compound might be used further to develop IDO inhibitors synthetically. ${ }^{75}$

\section{Tryptamine (TRY)}

Although the tryptophan metabolism is mainly degraded through kynurenine pathway, other tryptophan active products include TRY, melatonin, serotonin and $N$-dimethyltryptamine (DMT). Recently, a study determined IDO inhibitory activities of these compounds. Serotonin and melatonin were not shown to inhibit IDO even at high concentrations, whereas DMT and TRY inhibited IDO activity noncompetitively with $\mathrm{K} i$ values of 506 and $160 \mu \mathrm{M}$, respectively. ${ }^{79}$

\section{Epigallocatechin gallate}

EGCG is a phytochemical and an active component of green tea that exerts chemoprotective role and exhibits anticancer

Table 3 Physicochemical properties of selected natural inhibitors

\begin{tabular}{|c|c|c|c|c|}
\hline Natural inhibitor & $\begin{array}{l}\text { Molecular } \\
\text { weight (Da) }\end{array}$ & $\begin{array}{l}\text { Polar surface } \\
\text { area }\left(\AA^{2}\right)\end{array}$ & $\begin{array}{l}\text { Molecular surface } \\
\text { area }\left(\AA^{2}\right)\end{array}$ & $\begin{array}{l}\text { Partition } \\
\text { coefficient (log P) }\end{array}$ \\
\hline Brassinin & 236.35 & 27.82 & 310.98 & 3.28 \\
\hline Annulin A & 360.35 & 110.13 & 501.95 & 3.20 \\
\hline Annulin B & 386.39 & 106.97 & 547.34 & 4.13 \\
\hline Adociaquinone $\mathrm{A}$ & 520.77 & 110.52 & 423.438 & 1.10 \\
\hline Adociaquinone B & 423.43 & 110.52 & 520.92 & 1.10 \\
\hline Exiguamine $\mathrm{A}$ & 492.50 & 146.03 & 647.56 & -1.85 \\
\hline Tryptamine & |60.2| & 41.81 & 252.62 & 1.49 \\
\hline Curcumin & 368.37 & 93.06 & 509.73 & 4.12 \\
\hline Epigallocatechin gallate & 458.37 & 197.37 & 556.67 & 3.08 \\
\hline Tryptanthrin & 248.23 & 49.74 & 299.16 & 2.40 \\
\hline 3,3'-Diindolylmethane & 246.30 & 31.58 & 352.74 & 4.26 \\
\hline p-Coumaric acid & 164.15 & 57.53 & 216.51 & 1.83 \\
\hline Thielavin & 580.62 & |48.82 & 869.53 & 9.30 \\
\hline
\end{tabular}

Note: Physicochemical properties of selected natural inhibitors retrieved from Watkins et al. ${ }^{147}$ 
A<smiles>CSC(=S)NCc1c[nH]c2ccccc12</smiles>

C<smiles>CCc1c(C)cc2c(c1O)C(=O)C1OC(C)(C(=O)OC)C(=O)C(C)(C)C1C2=O</smiles>

E<smiles>CC12CCCc3coc(c31)C(=O)c1cc3c(cc12)C(=O)C1=C(NCCS1(=O)=O)C3=O</smiles>

\section{G}<smiles>NCCc1c[nH]c2ccccc12</smiles>

H<smiles>COc1cc(C=CC(=O)CC(=O)CCc2ccc(O)c(OC)c2)ccc1O</smiles>

$\mathbf{L}$<smiles>O=C1c2ccccc2-n2c1nc1ccccc1c2=O</smiles><smiles>O=C(O)CCc1ccc(O)cc1</smiles>

B<smiles>CCc1c(C)cc2c(c1O)C(=O)C1=C(C2=O)C(O)(C(=O)OC)OC(C)(C)O1</smiles>

D<smiles>CC12CCCc3coc(c31)C(=O)c1cc3c(cc12)C(=O)C1=C(C3=O)S(=O)(=O)CCN1</smiles>

$\mathbf{F}$<smiles>[Tl]</smiles>

K<smiles>c1ccc2c(Cc3c[nH]c4ccccc34)c[nH]c2c1</smiles>

M<smiles>Cc1cc(O)c(C)c(OC(=O)c2c(C)c(O)c(C(=O)Oc3c(C)c(C)c(C(=O)O)c(C)c3C)c(C)c2O)c1C</smiles>

Figure 2 Natural inhibitors with structures.

Notes: (A) Brassinin, ${ }^{76}(\mathbf{B})$ annulin $A,{ }^{78}(\mathbf{C})$ annulin $B,{ }^{78}(\mathbf{D})$ adociaquinone $A,{ }^{72}(\mathbf{E})$ adociaquinone $B,{ }^{72}(\mathbf{F})$ exiguamine $A,{ }^{75}(\mathbf{G})$ tryptamine ${ }^{79}(\mathbf{H})$ curcumin,${ }^{83}(\mathbf{I})$ epigallocatechin gallate, ${ }^{80}(\mathbf{J})$ tryptanthrin, ${ }^{85}(\mathbf{K}) 3,3^{\prime}$-dindolylmethane, ${ }^{75}(\mathbf{L})$ p-coumaric acid, ${ }^{88}$ and $(\mathbf{M})$ thielavin. ${ }^{59}$ 
effects in several organs. Recent studies revealed that the treatment of EGCG inhibits IDO enzyme activity in CRC cells through the inhibition of STAT1 activation. ${ }^{80}$

\section{Crinum latifolium leaf extract}

Genus Crinum (Amaryllidaceae) consists of plants comprising $\sim 130$ species, widely present and frequently used in traditional medicine worldwide. A strong suppressive action of leaf extract of C. latifolium activity of IDO in prostate tumor cells has been demonstrated. This inhibitory action is specifically attributed to alkaloids present in C. latifolium. ${ }^{81}$

\section{Carthamus tinctorius}

C. tinctorius, the herbaceous plant also known as safflower, belongs to the family Asteraceae and traditionally used in Chinese medicine. In Mediterranean area, its role has been recently demonstrated as anticancer, antihelmintic and diuretic. Three lignans (a group of chemical compounds found in plants), namely trachelogenin, matairesinol and arctigenin, were isolated and investigated for their inhibitory capability for IDO. Subsequent experiments showed that trachelogenin and arctigenin prevent the mitogen-induced breakdown of tryptophan in a dose-dependent manner, and no negative influence of these compounds recorded on the viability of cells. ${ }^{82}$

\section{Curcumin}

Curcumin, a phenolic natural and active compound, obtained from Curcuma longa (turmeric) possesses anti-inflammatory, anticancer and antioxidant properties. ${ }^{83}$ Recently, it was revealed that curcumin-inhibited IFN- $\gamma$ induced IDO activity both at protein and messenger RNA (mRNA) level through Janus kinase (JAK) $1 / 2$ and protein kinase $\mathrm{C}$ delta (PKC $\Delta$ ) signaling pathways. Thus, this immunomodulatory effect of curcumin might be exploited therapeutically to treat and control various types of cancers. ${ }^{74}$

\section{3,3'-Diindolylmethane (DIM)}

The nutritional supplement, indole-3-carbinol and its metabolites, DIM contain indole ring and are structurally similar to tryptophan. It has been reported that DIM competitively inhibit tryptophan degradation. It has a moderate activity which is an IDO-specific inhibitor. ${ }^{75}$

\section{Tryptanthrin}

A natural product tryptanthrin is found in Polygonum tinctorium and Isatis tinctoria. These two plants are frequently used in Chinese medicine. Tryptanthrin has revealed immunomodulatory ${ }^{76}$ and various inhibitory activities against microbes and parasites. ${ }^{84}$ Tryptanthrin has been identified as a potent novel IDO inhibitor, which has an $\mathrm{IC}_{50}$ of $7.15 \mu \mathrm{M}^{85}$ and reported to have $\mathrm{K} i$ value of $4.8 \mu \mathrm{M}^{78}$

\section{Neem (Azadirachta indica) leaf glycoprotein (NLGP)}

Various immunotherapeutic strategies are used to treat cancer by downregulating IDO activity, possibly by using IDO inhibitors, and thus reducing T-regs. NLGP, the naturally occurring immune system modulator, has revealed various unique activities. Most significant of which are to inhibit T-regs and mature DCs. As IDO is induced by T-regs and their hyperactivity is the hallmark of cancer, thus it has been proposed that NLGP may inhibit IDO induction in DCs by suppressing T-regs. ${ }^{86}$

\section{p-Coumaric acid}

$p$-Coumaric acid exists abundantly in various plant products, fruits and vegetables, for example, potatoes, tea and beans, and has been anticipated to exhibit antioxidant activity. ${ }^{87}$ Numerous antioxidants are suggested to suppress IDO activity through posttranscriptional and translational regulations. In addition, it has been demonstrated to inhibit prolactin secretion. Lymphoid organs and pituitary gland also secrete prolactin. Based on the fact that prolactin increases IDO activity induced by IFN- $\gamma$, researchers have proposed that $p$-coumaric acid and various other antioxidants suppress IDO activity in macrophages. ${ }^{88}$

\section{Polyphenols}

Numerous flavonoids have been reported to exhibit antiinflammatory and antioxidant activities. ${ }^{89}$ However, the chemical structure is the main determinant of their potency. Wogonin, baicalein, apigenin and chrysin have shown similar basic flavonone chemical structure. Despite possessing $\mathrm{OH}$ group in their structures, all these compounds inhibit the IDO-1 protein in a similar way. ${ }^{90}$

\section{Benzomalvin}

Jang et al isolated benzomalvin, a new benzodiazepine from the extracts of fungus during their search for IDO inhibitors. During the screening process, one of the culture broths from soil fungus showed activity and was later identified as Penicillium sp. on the basis of having sequence homology with two species of Penicillium sp. The $\mathrm{IC}_{50}$ values for benzomalvin were found to be $21.4 \pm 1.2 \mu \mathrm{M} .^{78,91}$ 


\section{Thielavin}

Jang et al have identified several IDO inhibitors from the microbial source, especially soil fungi during the past few years. Thielavin-Q a new benzoate trimer is one of the compounds identified by them, recently, from the broth of Coniochaeta sp. during the fermentation process. Thielavin-Q has shown an $\mathrm{IC}_{50}$ value for $\mathrm{IDO}^{92}$ of $15 \mu \mathrm{M}^{59}$

\section{$\beta$-Lapachone}

$\beta$-Lapachone occurs naturally and is derived from 1,2naphthoquinone. It is already well-known that it possesses anticancer properties and based on that it has been advanced into the clinical trials. Recently, Flick et al discovered that $\beta$-lapachone also possesses nanomolar IDO inhibitory enzymatic activity and shows $\mathrm{K} i$ value of $0.10-0.45 \mu \mathrm{M} .^{78,93}$

\section{Naphthoquinones}

After elucidating the crystal structure of IDO in $2006,{ }^{35}$ it practically became possible to predict which other nuclei could become potential inhibitors. Simultaneously, other compounds such as the naphthoquinone were identified, which were extracted from marine invertebrates. ${ }^{94}$ These compounds presented $\mathrm{K} i$ values in nanomoles; however, they were shown to be inactive in cellular assays, which suggested that they faced difficulties in crossing the cell membrane..$^{95}$

\section{Synthetic inhibitors}

Physiochemical properties and structures of synthetic inhibitors are described in Table 4 and Figure 3.

\section{Norharman (9H-pyrido [3,4-b]indole)}

Norharman, also termed as $\beta$-carboline is a non-competitive inhibitor of IDO. Norharman (Ki of $176 \mu \mathrm{M})$ competes with molecular oxygen $\left(\mathrm{O}_{2}\right)$, necessary for the activity of dioxygenase. ${ }^{96}$

\section{4-Phenylimidazole (PIM)}

PIM is another noncompetitive inhibitor discovered in 1989 and has a different mechanism of action to that of Norharman. PIM (Ki of $8 \mu \mathrm{M}$ ) binds to the enzyme at the inactive ferric $\left(\mathrm{Fe}^{3+}\right)$ form and prevents its reduction to the catalytically active ferrous form. ${ }^{97}$

\section{Salicylates and glucocorticoids}

A study involving prostaglandins revealed that enzymes phospholipase A2 and cyclooxygenase-2 (COX-2), which are essential for its synthesis, play a significant role in IDO induction through IFN- $\gamma$ pathway. ${ }^{98}$ It was also assessed that these inhibitors are able to block this induction. ${ }^{99}$

\section{Antioxidants}

Antioxidants, such as ascorbic acid, tocopherols and tocotrienols, that inhibit reactive oxygen species also perform an important role in the IDO inhibition-mediated activity by IFN- $\gamma$ in macrophages-derived monocytes. ${ }^{100}$

\section{5-Bromo-brassinin}

Another natural compound called brassinin was identified ${ }^{72,101}$ from Chinese cabbage and broccoli with a $\mathrm{K} i$ of $27.9 \mu \mathrm{M}$. Beside its synthetic derivative, 5-bromo-brassinin with a $\mathrm{K} i$ of $24.5 \mu \mathrm{M}$ presented chemoprotective activity in mammary cancer and melanomas in animal models. ${ }^{102,103}$

\section{Nitric oxide}

Nitric oxide (NO) negatively modulates the expression of IDO activity. ${ }^{104}$ The same happens with the production of

Table 4 Physicochemical properties of selected synthetic inhibitors

\begin{tabular}{|c|c|c|c|c|}
\hline Synthetic inhibitors & $\begin{array}{l}\text { Molecular } \\
\text { weight (Da) }\end{array}$ & $\begin{array}{l}\text { Polar surface } \\
\text { area }\left(A^{2}\right)\end{array}$ & $\begin{array}{l}\text { Molecular surface } \\
\text { area }\left(A^{2}\right)\end{array}$ & $\begin{array}{l}\text { Partition } \\
\text { coefficient (log P) }\end{array}$ \\
\hline Norharman (9H-pyrido [3,4-b]indole) & 168.19 & 28.68 & 230.63 & 1.87 \\
\hline 4-Phenylimidazole & 144.17 & 28.68 & 211.56 & 1.89 \\
\hline Salicylic acid & 138.12 & 57.53 & 183.54 & 1.98 \\
\hline Ascorbic acid & 176.12 & 107.22 & 208.27 & -1.91 \\
\hline Nitric oxide & 30.00 & 34.14 & 48.22 & -0.35 \\
\hline I-Methyl tryptophan & 218.25 & 68.11 & 322.23 & 1.32 \\
\hline 2-Mercapto-benzothiazole & 167.25 & 12.89 & 191.43 & 2.89 \\
\hline 2-Mercapto-4-phenylthiazole & 193.28 & 12.89 & 236.29 & 3.44 \\
\hline Phenylthiazole & 161.22 & 12.89 & 215.12 & 2.66 \\
\hline Imidodicarbonimidic diamide & 101.11 & $1 \mathrm{I} 1.77$ & 130.40 & -1.46 \\
\hline 4-Amino-1,2,5-oxadiazole-3-carboximidamide & 127.10 & || $4.8 \mid$ & 147.82 & -1.37 \\
\hline Phenformin & 205.25 & 102.78 & 302.68 & 0.34 \\
\hline Cinnabarinic acid & 300.22 & 139.28 & 311.10 & 0.44 \\
\hline
\end{tabular}




\section{A}<smiles>c1ccc2c(c1)[nH]c1cnccc12</smiles>

C<smiles>CSC(=S)NCC1=NCc2ccc(Br)cc21</smiles>

E<smiles>Cn1cc(C[C@H](N)C(=O)O)c2ccccc21</smiles>

G<smiles>S=c1[nH]c(-c2ccccc2)cs1</smiles>

|<smiles>N=C(N)NC(=N)NCCc1ccccc1</smiles>

B<smiles>c1ccc(-c2cnc[nH]2)cc1</smiles>

D<smiles>[N]=O</smiles>

$\mathbf{F}$<smiles>S=c1[nH]c2ccccc2s1</smiles>

$\mathrm{H}$<smiles>CN1C(=O)C(Cc2c[nH]c3ccccc23)NC1=S</smiles>

J<smiles>c1ccc(-c2nccs2)cc1</smiles><smiles>Nc1c(C(=O)O)c2nc3c(C(=O)O)cccc3oc-2cc1=O</smiles>

Figure 3 Synthetic inhibitors with structures

Notes: (A) Norhaman, ${ }^{96}$ (B) 4-phenylimidazole, ${ }^{97}$ (C) 5-bromo-brassinin, ${ }^{102}$ (D) nitric oxide, ${ }^{104}$ (E) I-methyl tryptophan, ${ }^{62}$ (F) 2-mercaptobenzothiazole, ${ }^{108}$ (G) 2-mercapto4-phenylthiazole, ${ }^{108}(\mathbf{H})$ methyl-thiohydantoin-L-tryptophan, ${ }^{108}(\mathbf{I})$ phenformin, ${ }^{73}(\mathbf{J})$ phenylthiazole, ${ }^{108}$ and $(\mathbf{K})$ cinnabarinic acid. ${ }^{95}$

inducible NO synthase, ${ }^{104}$ which directly interferes with IDO activity ${ }^{104,105}$ and eventually promotes degradation through proteolytic cleavage. ${ }^{106}$ This led to the belief that certain agonists exhibit the potential to reverse the state of immunosuppression caused by IDO in cases of cancer, thus contributing to anticancer therapy.

\section{I-MT}

For a long time, the best anti-IDO compound was derived from changes in the molecule tryptophan, including inserting a methyl group in the nitrogen present in the indole ring, resulting in a synthetically active 1-MT with $\mathrm{K} i$ of $34 \mu \mathrm{M}$. The catalytic activity of the enzyme was affected by replacing the nitrogen in the ring with an oxygen or sulfur, ${ }^{69}$ resulting in enhanced affinity to inhibit the enzyme in nanomolar quantities. ${ }^{62,107}$ So far 1-MT is the only compound that has been allowed to be passed into clinical trials based on its potency, efficacy and safety profile..$^{59}$

\section{2-Mercapto-benzothiazole, 2-mercapto- 4-phenylthiazole and phenylthiazole}

In 2010, a study was conducted based on the structureactivity relationship between IDO and 55 possible synthetic inhibitors, ${ }^{108}$ which were analyzed by docking. It was assessed that 2-mercaptobenzothiazole, 2-mercaptophenylthiazole and phenylthiazole were characterized as the 
most efficient. These compounds presented $\mathrm{K} i$ of 7.4 and $8.9 \mu \mathrm{M}$, respectively, and exhibited safety and efficacy both in the cellular and cell-free systems. In this study, Röhrig et al demonstrated that for an efficient inhibitory action, IDO inhibitors should contain: 1) a bicyclic fragment to fill the aromatic binding site, 2) an atom with pairs of free electrons that can coordinate with the iron present on the heme molecule (such as sulfur, oxygen or nitrogen), 3) a group able to establish van der Walls connections and 4) a group able to establish hydrogen bonds with fragments of specific amino acid structures on IDO.

\section{Ketoindoles}

Recently, noncompetitive inhibitors of IDO have been discovered with a micromolar range of inhibitory potency. A screening strategy was used to discover these compounds based on virtual tools, such as filters for exhibiting high throughput docking profiles. Calorimetric inhibition of in vitro assays revealed $\mathrm{IC}_{50}$ of $13 \mu \mathrm{M}^{61}$ with a $\mathrm{K} i$ of $190 \mu \mathrm{M}^{109,110}$

\section{Indol-2-yl ethanones}

In an effort to investigate novel compounds for IDO inhibition, indol-2-yl ethanones were identified and in vivo and in vitro tests were conducted to access the inhibitory concentrations. ${ }^{110}$ Results revealed that variations in inhibitory concentrations were obtained by altering the substituent at positions 5 and 6 of the indole ring, leading to $\mathrm{IC}_{50}$ of $24-153 \mu \mathrm{M}$.

\section{Aminophenoxazinones}

Oxidative cyclo-oxidation of 2-aminophenols led to the formation of a range of 2-aminophenoxazin-3-one compounds. ${ }^{111}$ Naturally, this reaction is catalyzed by a copper-containing oxidase enzyme referred as phenoxazinone synthase. A series of results were obtained after certain experiments to evaluate the concentrations required to inhibit IDO. It was reported that cinnabarinic acid was the most potent inhibitor out of the series of compounds with the $\mathrm{IC}_{50}$ of $0.46 \mu \mathrm{M}$ with a $\mathrm{K} i$ at $326 \mathrm{nM}$.

\section{Methyl-thiohydantoin-L-tryptophan (MTH-Trp)}

To find a structurally distinct inhibitor for IDO, several commercially available compounds with indolamine, as the key component, were identified and tested. After biochemical analysis, the results indicated that $\mathrm{MTH}-\mathrm{Trp}$ acts as a competitive inhibitor of IDO with $\mathrm{K} i$ of $12 \mu \mathrm{M}$. Interestingly, in a cell-based assay, MTH-Trp shows $\sim 20$-fold more potency than 1-MT. ${ }^{73}$

\section{Imidodicarbonimidic diamide}

A non-indolic IDO inhibitor was identified with an excellent potency against IDO. This compound which is classified as NSC 401366 has not been reported to have any other biological targets except its activity against IDO. On the basis of the experimental data, it was assessed that it demonstrated a $\mathrm{K} i$ of $1.5 \pm 2 \mu \mathrm{M} .{ }^{95}$

\section{4-Amino- I,2,5-oxadiazole-3- carboximidamide}

During the high throughput screening of a collection (Incyte's corporate) of compounds, a potent inhibitor of IDO was identified. This compound serves as a competitive inhibitor with a $\mathrm{K} i$ of 1.5 and an $\mathrm{IC}_{50}$ of $1 \mu \mathrm{M}$ when tested in HeLa cells. It has been confirmed by absorption spectroscopy that this compound binds to the active site of heme in the ferrous form of IDO. ${ }^{75}$

\section{Conclusion}

Targeted drug delivery to cancer cells has been achieved by nanomedicine. Nanotechnology is used to design specific drug delivery platforms that have the ability to carry anticancerous compounds to the target cells ensuring safety and efficacy of the treatment.

Nanomedicine has taken a giant step into cancer therapeutics, but researchers still face a number of challenges in this field. Most of the nanomedicines have been in the preclinical phase in the drug discovery pipeline and it will take years in order to lead them with confidence from laboratory to the bedside. Undoubtedly, nanomedicine has shown foreseeable progress in the last decade and is a leading determinant for personalized and targeted cancer treatment.

A nanotechnology-based device has been tested, which can detect the association of protein that interacts with thioredoxin and functions to distinguish between the prostate cancer associated stroma from that of benign prostatic hyperplasia. ${ }^{112}$

In a preclinical study, oral presentation of a nanoparticleencapsulated active ingredient of green tea showed greater therapeutic benefits to combat xenografts of prostate cancer in mice presentation unencapsulated control. ${ }^{113}$

Encapsulation of lutelina, a compound naturally found in the green vegetables in a water-soluble polymer to form nanoparticles, improved the ability of the compound to inhibit the growth of human cells of lung cancer and head and neck in crops cellular and mice, suggesting that the administration of nanoparticles similar to natural nutritional supplements could be applied in chemoprevention. ${ }^{114}$ 
A multifunctional nanomedicine platform created from a single polymer can increase the sensitivity of the images, convert efficiently light into heat within tumors (photothermal therapy) and effectively deliver drugs in tumors, demonstrating the wide range of relevant clinical uses. ${ }^{115}$

IDO inhibition is a pivotal area of research in cancer immunotherapy. A constitutive IDO expression in most human tumors is demonstrated in 2003. ${ }^{116,117}$ Commercial scale production of IDO inhibitors in conjunction with nanomedicine is, therefore, an important area of immunotherapy that should develop fairly soon. In conclusion, naturally occurring or synthetic IDO inhibitors have been shown to contain an antiproliferative function for cancer cells. These inhibitors are bound to find their way into the pharmaceutical industry to play a critical role in cancer immunotherapy, ${ }^{118-120}$ organ transplantation and treatment of infectious and autoimmune diseases.

\section{Acknowledgment}

We acknowledge the contributions of all researchers whose work could not be cited in this review because of space limitations.

\section{Author contributions}

All authors contributed toward data analysis, drafting and critically revising the paper and agree to be accountable for all aspects of the work.

\section{Disclosure}

The authors report no conflicts of interest in this work.

\section{References}

1. Tacar O, Sriamornsak P, Dass CR. Doxorubicin: an update on anticancer molecular action, toxicity and novel drug delivery systems. J Pharm Pharmacol. 2013;65(2):157-170.

2. Peer D, Karp JM, Hong S, Farokhzad OC, Margalit R, Langer R. Nanocarriers as an emerging platform for cancer therapy. Nat Nanotechnol. 2007;2(12):751-760.

3. Prabhakar U, Maeda H, Jain RK, et al. Challenges and key considerations of the enhanced permeability and retention effect for nanomedicine drug delivery in oncology. Cancer Res. 2013;73(8): 2412-2417.

4. Noble CO, Kirpotin DB, Hayes ME, et al. Development of ligandtargeted liposomes for cancer therapy. Expert Opin Ther Targets. 2004; 8(4):335-353.

5. Ta HT, Dass CR, Dunstan DE. Injectable chitosan hydrogels for localised cancer therapy. J Control Release. 2008;126(3):205-216.

6. Khemtong C, Kessinger CW, Gao J. Polymeric nanomedicine for cancer MR imaging and drug delivery. Chem Commun (Camb). 2009;(24): 3497-3510.

7. Huang X, El-Sayed IH, Qian W, El-Sayed MA. Cancer cell imaging and photothermal therapy in the near-infrared region by using gold nanorods. $J$ Am Chem Soc. 2006;128(6):2115-2120.

8. Liu KK, Zheng WW, Wang CC, et al. Covalent linkage of nanodiamondpaclitaxel for drug delivery and cancer therapy. Nanotechnology. 2010; 21(31):315106.
9. Davis ME. The first targeted delivery of siRNA in humans via a selfassembling, cyclodextrin polymer-based nanoparticle: from concept to clinic. Mol Pharm. 2009;6(3):659-668.

10. Herbertson RA, Tebbutt NC, Lee FT, et al. Phase I biodistribution and pharmacokinetic study of Lewis Y-targeting immunoconjugate CMD193 in patients with advanced epithelial cancers. Clin Cancer Res. 2009; 15(21):6709-6715.

11. O’Neal DP, Hirsch LR, Halas NJ, Payne JD, West JL. Photo-thermal tumor ablation in mice using near infrared-absorbing nanoparticles. Cancer Lett. 2004;209(2):171-176.

12. Dabbagh A, Mahmoodian R, Abdullah BJ, Abdullah H, Hamdi M, Abu Kasim NH. Low-melting-point polymeric nanoshells for thermaltriggered drug release under hyperthermia condition. Int J Hyperthermia. 2015;31(8):920-929.

13. Wu CC, Yang YC, Hsu YT, et al. Nanoparticle-induced intraperitoneal hyperthermia and targeted photoablation in treating ovarian cancer. Oncotarget. 2015;6(29):26861-26875.

14. Malam Y, Loizidou M, Seifalian AM. Liposomes and nanoparticles: nanosized vehicles for drug delivery in cancer. Trends Pharmacol Sci. 2009;30(11):592-599.

15. Jhaveri AM, Torchilin VP. Multifunctional polymeric micelles for delivery of drugs and siRNA. Front Pharmacol. 2014;5:77.

16. Gabizon A, Catane R, Uziely B, et al. Prolonged circulation time and enhanced accumulation in malignant exudates of doxorubicin encapsulated in polyethylene-glycol coated liposomes. Cancer Res. 1994;54(4): 987-992.

17. Gao H, Yang Z, Zhang S, et al. Ligand modified nanoparticles increases cell uptake, alters endocytosis and elevates glioma distribution and internalization. Sci Rep. 2013;3:2534.

18. Kesik V, Honca T, Gulgun M, et al. Myostatin as a marker for doxorubicin induced cardiac damage. Ann Clin Lab Sci. 2016;46(1):26-31.

19. Shima H, Ozasa H, Tsuji T, et al. Response to chemotherapy with carboplatin plus albumin-bound paclitaxel in a patient with lymphoepithelioma-like thymic carcinoma: a case report. Mol Clin Oncol. 2016;4(5):715-718.

20. Fu S, Culotta KS, Falchook GS, et al. Erratum to: pharmacokinetic evaluation of nanoparticle albumin-bound paclitaxel delivered via hepatic arterial infusion in patients with predominantly hepatic metastases. Cancer Chemother Pharmacol. 2016;77(4):881.

21. Krishnamachari Y, Geary SM, Lemke CD, Salem AK. Nanoparticle delivery systems in cancer vaccines. Pharm Res. 2011;28(2):215-236.

22. Boisselier E, Astruc D. Gold nanoparticles in nanomedicine: preparations, imaging, diagnostics, therapies and toxicity. Chem Soc Rev. 2009;38(6): 1759-1782.

23. Santra S, Jativa SD, Kaittanis C, Normand G, Grimm J, Perez JM. Gadolinium-encapsulating iron oxide nanoprobe as activatable NMR/ MRI contrast agent. ACS Nano. 2012;6(8):7281-7294.

24. Alharbi KK, Al-Sheikh YA. Role and implications of nanodiagnostics in the changing trends of clinical diagnosis. Saudi J Biol Sci. 2014 21(2):109-117.

25. Menciassi A, Sinibaldi E, Pensabene V, Dario P. From miniature to nano robots for diagnostic and therapeutic applications. Conf Proc IEEE Eng Med Biol Soc. 2010;2010:1954-1957.

26. Jordan A. Nanotechnologie und Konsequenzen für chirurgische Onkologie. [Nanotechnology and consequences for surgical oncology]. Kongressbd Dtsch Ges Chir Kongr. 2002;119:821-828. German.

27. Zolnik BS, Gonzalez-Fernandez A, Sadrieh N, Dobrovolskaia MA Nanoparticles and the immune system. Endocrinology. 2010;151(2): 458-465.

28. Kasturi SP, Skountzou I, Albrecht RA, et al. Programming the magnitude and persistence of antibody responses with innate immunity. Nature. 2011;470(7335):543-547.

29. Siddiqi NJ. Effect of gold nanoparticles on superoxide dismutase and indoleamine 2,3-dioxygenase in various rat tissues. Indian J Biochem Biophys. 2014;51(2):156-159.

30. Brigger I, Dubernet C, Couvreur P. Nanoparticles in cancer therapy and diagnosis. Adv Drug Deliv Rev. 2002;54(5):631-651. 
31. Adiseshaiah PP, Crist RM, Hook SS, McNeil SE. Nanomedicine strategies to overcome the pathophysiological barriers of pancreatic cancer. Nat Rev Clin Oncol. 2016;13(12):750-765.

32. Viswanath B, Kim S, Lee K. Recent insights into nanotechnology development for detection and treatment of colorectal cancer. Int J Nanomedicine. 2016;11:2491-2504.

33. Chen J, Shao R, Zhang XD, Chen C. Applications of nanotechnology for melanoma treatment, diagnosis, and theranostics. Int J Nanomedicine. 2013;8:2677-2688.

34. Chen J, Gu W, Yang L, et al. Nanotechnology in the management of cervical cancer. Rev Med Virol. 2015;25(Suppl 1):72-83.

35. Sugimoto H, Oda S, Otsuki T, Hino T, Yoshida T, Shiro Y. Crystal structure of human indoleamine 2,3-dioxygenase: catalytic mechanism of 2 incorporation by a heme-containing dioxygenase. Proc Natl Acad Sci US A. 2006;103(8):2611-2616.

36. Mellor AL, Chandler P, Lee GK, et al. Indoleamine 2,3-dioxygenase, immunosuppression and pregnancy. J Reprod Immunol. 2002;57(1-2): 143-150.

37. Mellor A. Indoleamine 2,3 dioxygenase and regulation of T cell immunity. Biochem Biophys Res Commun. 2005;338(1):20-24.

38. Boasso A, Herbeuval JP, Hardy AW, et al. HIV inhibits CD4+ T-cell proliferation by inducing indoleamine 2,3-dioxygenase in plasmacytoid dendritic cells. Blood. 2007;109(8):3351-3359.

39. Platten M, Wick W, Van den Eynde BJ. Tryptophan catabolism in cancer: beyond IDO and tryptophan depletion. Cancer Res. 2012;72(21): 5435-5440.

40. Soliman H, Rawal B, Fulp J, et al. Analysis of indoleamine 2-3 dioxygenase (IDO1) expression in breast cancer tissue by immunohistochemistry. Cancer Immunol Immunother. 2013;62(5):829-837.

41. Sakurai K, Enomoto K, Kitajima A, Tani M, Amano S, Shiono M. [Indoleamine 2,3-dioxygenase expression in breast cancer patients during chemotherapy]. Gan To Kagaku Ryoho. 2008;35(12):2265-2267. Japanese.

42. Basu GD, Tinder TL, Bradley JM, et al. Cyclooxygenase-2 inhibitor enhances the efficacy of a breast cancer vaccine: role of IDO. J Immunol. 2006;177(4):2391-2402.

43. Sakurai K, Fujisaki S, Nagashima S, et al. [Study of indoleamine 2,3dioxygenase expression in patients of thyroid cancer]. Gan To Kagaku Ryoho. 2011;38(12):1927-1929. Japanese.

44. Witkiewicz AK, Costantino CL, Metz R, et al. Genotyping and expression analysis of IDO2 in human pancreatic cancer: a novel, active target. J Am Coll Surg. 2009;208(5):781-787; discussion 787-789.

45. Witkiewicz A, Williams TK, Cozzitorto J, et al. Expression of indoleamine 2,3-dioxygenase in metastatic pancreatic ductal adenocarcinoma recruits regulatory T cells to avoid immune detection. J Am Coll Surg. 2008; 206(5):849-854; discussion 854-846.

46. Feder-Mengus C, Wyler S, Hudolin T, et al. High expression of indoleamine 2,3-dioxygenase gene in prostate cancer. Eur J Cancer. 2008; 44(15):2266-2275.

47. Kallberg E, Wikstrom P, Bergh A, Ivars F, Leanderson T. Indoleamine 2,3-dioxygenase (IDO) activity influence tumor growth in the TRAMP prostate cancer model. Prostate. 2010;70(13):1461-1470.

48. Xie Q, Wang L, Zhu B, Wang Y, Gu J, Chen Z. [The expression and significance of indoleamine-2,3-dioxygenase in non-small cell lung cancer cell]. Zhongguo Fei Ai Za Zhi. 2008;11(1):115-119. Chinese.

49. Karanikas V, Zamanakou M, Kerenidi T, et al. Indoleamine 2,3-dioxygenase (IDO) expression in lung cancer. Cancer Biol Ther. 2007;6(8): 1258-1262.

50. Inaba $\mathrm{T}$, Ino $\mathrm{K}$, Kajiyama $\mathrm{H}$, et al. Indoleamine 2,3-dioxygenase expression predicts impaired survival of invasive cervical cancer patients treated with radical hysterectomy. Gynecol Oncol. 2010;117(3): $423-428$.

51. Ino K. Indoleamine 2,3-dioxygenase and immune tolerance in ovarian cancer. Curr Opin Obstet Gynecol. 2011;23(1):13-18.

52. Max D, Kuhnol CD, Burdach S, Niu L, Staege MS, Foll JL. Indoleamine-2,3-dioxygenase in an immunotherapy model for Ewing sarcoma. Anticancer Res. 2014;34(11):6431-6441.
53. Koorella C, Nair JR, Murray ME, Carlson LM, Watkins SK, Lee KP. Novel regulation of CD80/CD86-induced phosphatidylinositol 3-kinase signaling by NOTCH1 protein in interleukin-6 and indoleamine 2,3dioxygenase production by dendritic cells. J Biol Chem. 2014;289(11): 7747-7762.

54. Mohme M, Riethdorf S, Pantel K. Circulating and disseminated tumour cells - mechanisms of immune surveillance and escape. Nat Rev Clin Oncol. Epub 2016 Sep 20.

55. Bedognetti D, Maccalli C, Bader SB, Marincola FM, Seliger B. Checkpoint inhibitors and their application in breast cancer. Breast Care (Basel). 2016;11(2):108-115.

56. Manjili MH, Butler SE. Role of tregs in cancer dormancy or recurrence. Immunol Invest. 2016;45(8):759-766.

57. Shin DS, Ribas A. The evolution of checkpoint blockade as a cancer therapy: what's here, what's next? Curr Opin Immunol. 2015;33:23-35.

58. Munn DH, Mellor AL. Indoleamine 2,3-dioxygenase and tumor-induced tolerance. J Clin Invest. 2007;117(5):1147-1154.

59. Katz JB, Muller AJ, Prendergast GC. Indoleamine 2,3-dioxygenase in T-cell tolerance and tumoral immune escape. Immunol Rev. 2008;222: 206-221.

60. Muller AJ, Scherle PA. Targeting the mechanisms of tumoral immune tolerance with small-molecule inhibitors. Nat Rev Cancer. 2006;6(8): 613-625.

61. Alvaro T, Lejeune M, Salvado MT, et al. Outcome in Hodgkin's lymphoma can be predicted from the presence of accompanying cytotoxic and regulatory T cells. Clin Cancer Res. 2005;11(4):1467-1473.

62. Muller AJ, Malachowski WP, Prendergast GC. Indoleamine 2,3dioxygenase in cancer: targeting pathological immune tolerance with small-molecule inhibitors. Expert Opin Ther Targets. 2005;9(4):831-849.

63. Whiteside TL. Immune suppression in cancer: effects on immune cells, mechanisms and future therapeutic intervention. Semin Cancer Biol. 2006;16(1):3-15.

64. Sono M. Enzyme kinetic and spectroscopic studies of inhibitor and effector interactions with indoleamine 2,3-dioxygenase. 2. Evidence for the existence of another binding site in the enzyme for indole derivative effectors. Biochemistry. 1989;28(13):5400-5407.

65. Jiang T, Sun Y, Yin Z, Feng S, Sun L, Li Z. Research progress of indoleamine 2,3-dioxygenase inhibitors. Future Med Chem. 2015;7(2): 185-201.

66. Koblish HK, Hansbury MJ, Bowman KJ, et al. Hydroxyamidine inhibitors of indoleamine-2,3-dioxygenase potently suppress systemic tryptophan catabolism and the growth of IDO-expressing tumors. Mol Cancer Ther. 2010;9(2):489-498.

67. Grant R, Kapoor V. Inhibition of indoleamine 2,3-dioxygenase activity in IFN-gamma stimulated astroglioma cells decreases intracellular NAD levels. Biochem Pharmacol. 2003;66(6):1033-1036.

68. Sheridan C. IDO inhibitors move center stage in immuno-oncology. Nat Biotechnol. 2015;33(4):321-322.

69. Cady SG, Sono M. 1-Methyl-DL-tryptophan, beta-(3-benzofuranyl)-DLalanine (the oxygen analog of tryptophan), and beta-[3-benzo(b)thienyl]DL-alanine (the sulfur analog of tryptophan) are competitive inhibitors for indoleamine 2,3-dioxygenase. Arch Biochem Biophys. 1991;291(2): 326-333.

70. Wirthgen E, Kanitz E, Tuchscherer M, et al. Pharmacokinetics of 1-methyl-L-tryptophan after single and repeated subcutaneous application in a porcine model. Exp Anim. 2016;65(2):147-155.

71. Uyttenhove C, Pilotte L, Theate I, et al. Evidence for a tumoral immune resistance mechanism based on tryptophan degradation by indoleamine 2,3-dioxygenase. Nat Med. 2003;9(10):1269-1274.

72. Di Pucchio T, Danese S, De Cristofaro R, Rutella S. Inhibitors of indoleamine 2,3-dioxygenase: a review of novel patented lead compounds. Expert Opin Ther Pat. 2010;20(2):229-250.

73. Hou DY, Muller AJ, Sharma MD, et al. Inhibition of indoleamine 2,3dioxygenase in dendritic cells by stereoisomers of 1-methyltryptophan correlates with antitumor responses. Cancer Res. 2007;67(2):792-801. 
74. Jeong YI, Kim SW, Jung ID, et al. Curcumin suppresses the induction of indoleamine 2,3-dioxygenase by blocking the Janus-activated kinase-protein kinase Cdelta-STAT1 signaling pathway in interferon-gamma-stimulated murine dendritic cells. J Biol Chem. 2009;284(6):3700-3708.

75. Liu X, Newton RC, Friedman SM, Scherle PA. Indoleamine 2,3dioxygenase, an emerging target for anti-cancer therapy. Curr Cancer Drug Targets. 2009;9(8):938-952.

76. Takei Y, Kunikata T, Aga M, et al. Tryptanthrin inhibits interferongamma production by Peyer's patch lymphocytes derived from mice that had been orally administered staphylococcal enterotoxin. Biol Pharm Bull. 2003;26(3):365-367.

77. Gaspari P, Banerjee T, Malachowski WP, et al. Structure-activity study of brassinin derivatives as indoleamine 2,3-dioxygenase inhibitors. J Med Chem. 2006;49(2):684-692.

78. Rohrig UF, Majjigapu SR, Vogel P, Zoete V, Michielin O. Challenges in the discovery of indoleamine 2,3-dioxygenase 1 (IDO1) inhibitors. J Med Chem. 2015;58(24):9421-9437.

79. Tourino MC, de Oliveira EM, Belle LP, et al. Tryptamine and dimethyltryptamine inhibit indoleamine 2,3 dioxygenase and increase the tumor-reactive effect of peripheral blood mononuclear cells. Cell Biochem Funct. 2013;31(5):361-364.

80. Ogawa K, Hara T, Shimizu M, et al. (-)-Epigallocatechin gallate inhibits the expression of indoleamine 2,3-dioxygenase in human colorectal cancer cells. Oncol Lett. 2012;4(3):546-550.

81. Jenny M, Wondrak A, Zvetkova E, et al. Crinum latifolium leave extracts suppress immune activation cascades in peripheral blood mononuclear cells and proliferation of prostate tumor cells. Sci Pharm. 2011;79(2): 323-335.

82. Kuehnl S, Schroecksnadel S, Temml V, et al. Lignans from Carthamus tinctorius suppress tryptophan breakdown via indoleamine 2,3dioxygenase. Phytomedicine. 2013;20(13):1190-1195.

83. Kewitz S, Volkmer I, Staege MS. Curcuma contra cancer? Curcumin and Hodgkin's lymphoma. Cancer Growth Metastasis. 2013;6:35-52.

84. Mitscher LA, Baker W. Tuberculosis: a search for novel therapy starting with natural products. Med Res Rev. 1998;18(6):363-374.

85. Yang S, Li X, Hu F, et al. Discovery of tryptanthrin derivatives as potent inhibitors of indoleamine 2,3-dioxygenase with therapeutic activity in Lewis lung cancer (LLC) tumor-bearing mice. J Med Chem. 2013;56(21): 8321-8331.

86. Roy S, Barik S, Banerjee S, et al. Neem leaf glycoprotein overcomes indoleamine 2,3 dioxygenase mediated tolerance in dendritic cells by attenuating hyperactive regulatory $\mathrm{T}$ cells in cervical cancer stage IIIB patients. Hum Immunol. 2013;74(8):1015-1023.

87. Pei K, Ou J, Huang J, Ou S. p-Coumaric acid and its conjugates: dietary sources, pharmacokinetic properties and biological activities. J Sci Food Agric. 2016;96(9):2952-2962.

88. Kim SI, Jeong YI, Jung ID, et al. p-Coumaric acid inhibits indoleamine 2,3-dioxygenase expression in murine dendritic cells. Int Immunopharmacol. 2007;7(6):805-815.

89. Chen TS, Arslan F, Yin Y, et al. Enabling a robust scalable manufacturing process for therapeutic exosomes through oncogenic immortalization of human ESC-derived MSCs. J Transl Med. 2011;9:47.

90. Chen S, Corteling R, Stevanato L, Sinden J. Natural inhibitors of indoleamine 3,5-dioxygenase induced by interferon-gamma in human neural stem cells. Biochem Biophys Res Commun. 2012;429(1-2):117-123.

91. Jang JP, Jang JH, Soung NK, et al. Benzomalvin E, an indoleamine 2,3-dioxygenase inhibitor isolated from Penicillium sp. FN070315. J Antibiot (Tokyo). 2012;65(4):215-217.

92. Jang JP, Jang JH, Oh M, et al. Inhibition of indoleamine 2,3dioxygenase by thielavin derivatives from a soil fungus, Coniochaeta sp. 10F058. J Antibiot (Tokyo). 2014; 67(4):331-333.

93. Flick HE, Lalonde JM, Malachowski WP, Muller AJ. The tumorselective cytotoxic agent beta-Lapachone is a potent inhibitor of IDO1 Int J Tryptophan Res. 2013;6:35-45.

94. Brastianos HC, Vottero E, Patrick BO, et al. Exiguamine A, an indoleamine-2,3-dioxygenase (IDO) inhibitor isolated from the marine sponge Neopetrosia exigua. J Am Chem Soc. 2006;128(50):16046-16047.
95. Vottero E, Balgi A, Woods K, et al. Inhibitors of human indoleamine 2,3-dioxygenase identified with a target-based screen in yeast. Biotechnol J. 2006;1(3):282-288.

96. Eguchi N, Watanabe Y, Kawanishi K, Hashimoto Y, Hayaishi O. Inhibition of indoleamine 2,3-dioxygenase and tryptophan 2,3-dioxygenase by beta-carboline and indole derivatives. Arch Biochem Biophys. 1984; 232(2):602-609.

97. Kumar S, Jaller D, Patel B, et al. Structure based development of phenylimidazole-derived inhibitors of indoleamine 2,3-dioxygenase. J Med Chem. 2008;51(16):4968-4977.

98. Schroecksnadel K, Winkler C, Wirleitner B, Schennach H, Fuchs D. Aspirin down-regulates tryptophan degradation in stimulated human peripheral blood mononuclear cells in vitro. Clin Exp Immunol. 2005; 140(1):41-45.

99. Sayama S, Yoshida R, Oku T, Imanishi J, Kishida T, Hayaishi O. Inhibition of interferon-mediated induction of indoleamine 2,3dioxygenase in mouse lung by inhibitors of prostaglandin biosynthesis. Proc Natl Acad Sci U S A. 1981;78(12):7327-7330.

100. Thomas SR, Stocker R. Redox reactions related to indoleamine 2,3-dioxygenase and tryptophan metabolism along the kynurenine pathway. Redox Rep. 1999;4(5):199-220.

101. Banerjee T, Duhadaway JB, Gaspari P, et al. A key in vivo antitumor mechanism of action of natural product-based brassinins is inhibition of indoleamine 2,3-dioxygenase. Oncogene. 2008;27(20):2851-2857.

102. Mehta RG, Liu J, Constantinou A, et al. Cancer chemopreventive activity of brassinin, a phytoalexin from cabbage. Carcinogenesis. 1995; 16(2):399-404

103. Park EJ, Pezzuto JM. Botanicals in cancer chemoprevention. Cancer Metastasis Rev. 2002;21(3-4):231-255.

104. Alberati-Giani D, Malherbe P, Ricciardi-Castagnoli P, Kohler C, Denis-Donini S, Cesura AM. Differential regulation of indoleamine 2,3-dioxygenase expression by nitric oxide and inflammatory mediators in IFN-gamma-activated murine macrophages and microglial cells. J Immunol. 1997;159(1):419-426.

105. Daubener W, Posdziech V, Hadding U, MacKenzie CR. Inducible anti-parasitic effector mechanisms in human uroepithelial cells: tryptophan degradation vs. NO production. Med Microbiol Immunol. 1999;187(3):143-147.

106. Hucke C, MacKenzie CR, Adjogble KD, Takikawa O, Daubener W. Nitric oxide-mediated regulation of gamma interferon-induced bacteriostasis: inhibition and degradation of human indoleamine 2,3dioxygenase. Infect Immun. 2004;72(5):2723-2730.

107. Sono M, Roach MP, Coulter ED, Dawson JH. Heme-containing oxygenases. Chem Rev. 1996;96(7):2841-2888.

108. Röhrig UF, Awad L, Grosdidier A, et al. Rational design of indoleamine 2,3-dioxygenase inhibitors. J Med Chem. 2010;53(3):1172-1189.

109. Dolusic E, Larrieu P, Blanc S, et al. Discovery and preliminary SARs of keto-indoles as novel indoleamine 2,3-dioxygenase (IDO) inhibitors. Eur J Med Chem. 2011;46(7):3058-3065.

110. Dolusic E, Larrieu P, Blanc S, et al. Indol-2-yl ethanones as novel indoleamine 2,3-dioxygenase (IDO) inhibitors. Bioorg Med Chem. 2011; 19(4):1550-1561.

111. Pasceri R, Siegel D, Ross D, Moody CJ. Aminophenoxazinones as inhibitors of indoleamine 2,3-dioxygenase (IDO). Synthesis of exfoliazone and chandrananimycin A. J Med Chem. 2013;56(8): 3310-3317.

112. Singer E, Linehan J, Babilonia G, et al. Stromal response to prostate cancer: nanotechnology-based detection of thioredoxin-interacting protein partners distinguishes prostate cancer associated stroma from that of benign prostatic hyperplasia. PLoS One. 2013;8(6):e60562.

113. Khan N, Bharali DJ, Adhami VM, et al. Oral administration of naturally occurring chitosan-based nanoformulated green tea polyphenol EGCG effectively inhibits prostate cancer cell growth in a xenograft model. Carcinogenesis. 2014;35(2):415-423.

114. Majumdar D, Jung KH, Zhang H, et al. Luteolin nanoparticle in chemoprevention: in vitro and in vivo anticancer activity. Cancer Prev Res (Phila). 2014;7(1):65-73. 
115. Li Y, Lin TY, Luo Y, et al. A smart and versatile theranostic nanomedicine platform based on nanoporphyrin. Nat Commun. 2014;5:4712.

116. Sedlmayr P, Semlitsch M, Gebru G, et al. Expression of indoleamine 2,3-dioxygenase in carcinoma of human endometrium and uterine cervix. Adv Exp Med Biol. 2003;527:91-95.

117. Kai S, Goto S, Tahara K, Sasaki A, Kawano K, Kitano S. Inhibition of indoleamine 2,3-dioxygenase suppresses NK cell activity and accelerates tumor growth. J Exp Ther Oncol. 2003;3(6):336-345.

118. Chung TW, Tan KT, Chan HL, et al. Induction of indoleamine 2,3dioxygenase (IDO) enzymatic activity contributes to interferon-gamma induced apoptosis and death receptor 5 expression in human nonsmall cell lung cancer cells. Asian Pac J Cancer Prev. 2014;15(18): 7995-8001.

119. Chen SS, Corteling R, Stevanato L, Sinden J. Polyphenols inhibit indoleamine 3,5-dioxygenase-1 enzymatic activity - a role of immunomodulation in chemoprevention. Discov Med. 2012;14(78): 327-333.

120. Brandacher G, Winkler C, Schroecksnadel K, Margreiter R, Fuchs D. Antitumoral activity of interferon-gamma involved in impaired immune function in cancer patients. Curr Drug Metab. 2006;7(6):599-612.

121. Li X, Lu WL, Liang GW, et al. Effect of stealthy liposomal topotecan plus amlodipine on the multidrug-resistant leukaemia cells in vitro and xenograft in mice. Eur J Clin Invest. 2006;36(6):409-418.

122. Agrawal V, Paul MK, Mukhopadhyay AK. 6-Mercaptopurine and daunorubicin double drug liposomes-preparation, drug-drug interaction and characterization. J Liposome Res. 2005;15(3-4):141-155.

123. Wu J, Lu Y, Lee A, et al. Reversal of multidrug resistance by transferrin-conjugated liposomes co-encapsulating doxorubicin and verapamil. J Pharm Pharm Sci. 2007;10(3):350-357.

124. Tekade RK, Dutta T, Tyagi A, Bharti AC, Das BC, Jain NK. Surfaceengineered dendrimers for dual drug delivery: a receptor up-regulation and enhanced cancer targeting strategy. J Drug Target. 2008;16(10): 758-772.

125. Zhang J, Yang PL, Gray NS. Targeting cancer with small molecule kinase inhibitors. Nat Rev Cancer. 2009;9(1):28-39.

126. Tran MA, Smith CD, Kester M, Robertson GP. Combining nanoliposomal ceramide with sorafenib synergistically inhibits melanoma and breast cancer cell survival to decrease tumor development. Clin Cancer Res. 2008;14(11):3571-3581.

127. Dilnawaz F, Singh A, Mohanty C, Sahoo SK. Dual drug loaded superparamagnetic iron oxide nanoparticles for targeted cancer therapy. Biomaterials. 2010;31(13):3694-3706.

128. Lammers T, Subr V, Ulbrich K, et al. Simultaneous delivery of doxorubicin and gemcitabine to tumors in vivo using prototypic polymeric drug carriers. Biomaterials. 2009;30(20):3466-3475.

129. Lee IH, An S, Yu MK, Kwon HK, Im SH, Jon S. Targeted chemoimmunotherapy using drug-loaded aptamer-dendrimer bioconjugates. $J$ Control Release. 2011;155(3):435-441.

130. Ren Y, Kang CS, Yuan XB, et al. Co-delivery of as-miR-21 and 5-FU by poly(amidoamine) dendrimer attenuates human glioma cell growth in vitro. J Biomater Sci Polym Ed. 2010;21(3):303-314.

131. Kaneshiro TL, Lu ZR. Targeted intracellular codelivery of chemotherapeutics and nucleic acid with a well-defined dendrimer-based nanoglobular carrier. Biomaterials. 2009;30(29):5660-5666.
132. Kang SH, Cho HJ, Shim G, et al. Cationic liposomal co-delivery of small interfering RNA and a MEK inhibitor for enhanced anticancer efficacy. Pharm Res. 2011;28(12):3069-3078.

133. Xiao W, Chen X, Yang L, Mao Y, Wei Y, Chen L. Co-delivery of doxorubicin and plasmid by a novel FGFR-mediated cationic liposome. Int J Pharm. 2010;393(1-2):119-126.

134. Zucker D, Barenholz Y. Optimization of vincristine-topotecan combination - paving the way for improved chemotherapy regimens by nanoliposomes. J Control Release. 2010;146(3):326-333.

135. Song XR, Zheng Y, He G, et al. Development of PLGA nanoparticles simultaneously loaded with vincristine and verapamil for treatment of hepatocellular carcinoma. J Pharm Sci. 2010;99(12):4874-4879.

136. Batist G, Gelmon KA, Chi KN, et al. Safety, pharmacokinetics, and efficacy of CPX-1 liposome injection in patients with advanced solid tumors. Clin Cancer Res. 2009;15(2):692-700.

137. Tardi P, Johnstone S, Harasym N, et al. In vivo maintenance of synergistic cytarabine:daunorubicin ratios greatly enhances therapeutic efficacy. Leuk Res. 2009;33(1):129-139.

138. Hamilton A, Biganzoli L, Coleman R, et al. EORTC 10968: a phase I clinical and pharmacokinetic study of polyethylene glycol liposomal doxorubicin (Caelyx, Doxil) at a 6-week interval in patients with metastatic breast cancer. Ann Oncol. 2002;13(6):910-918.

139. Bedikian AY, Silverman JA, Papadopoulos NE, et al. Pharmacokinetics and safety of Marqibo (vincristine sulfate liposomes injection) in cancer patients with impaired liver function. J Clin Pharmacol. 2011; 51(8):1205-1212.

140. Silverman JA, Deitcher SR. Marqibo ${ }^{\circledR}$ (vincristine sulfate liposome injection) improves the pharmacokinetics and pharmacodynamics of vincristine. Cancer Chemother Pharmacol. 2013;71(3):555-564.

141. Gill PS, Wernz J, Scadden DT, et al. Randomized phase III trial of liposomal daunorubicin versus doxorubicin, bleomycin, and vincristine in AIDS-related Kaposi's sarcoma. J Clin Oncol. 1996;14(8): 2353-2364.

142. Bellott R, Auvrignon A, Leblanc T, et al. Pharmacokinetics of liposomal daunorubicin (DaunoXome) during a phase I-II study in children with relapsed acute lymphoblastic leukaemia. Cancer Chemother Pharmacol. 2001;47(1):15-21.

143. Lu D, Burris HA 3rd, Wang B, et al. Drug interaction potential of trastuzumab emtansine (T-DM1) combined with pertuzumab in patients with HER2-positive metastatic breast cancer. Curr Drug Metab. 2012; 13(7):911-922.

144. Younes A, Bartlett NL, Leonard JP, et al. Brentuximab vedotin (SGN-35) for relapsed CD30-positive lymphomas. $N$ Engl J Med. 2010;363(19):1812-1821.

145. Bradley AM, Devine M, DeRemer D. Brentuximab vedotin: an antiCD30 antibody-drug conjugate. Am J Health System Pharm. 2013; 70(7):589-597.

146. Ando M, Yonemori K, Katsumata N, et al. Phase I and pharmacokinetic study of nab-paclitaxel, nanoparticle albumin-bound paclitaxel, administered weekly to Japanese patients with solid tumors and metastatic breast cancer. Cancer Chemother Pharmacol. 2012;69(2):457-465.

147. Watkins R, Wu L, Zhang C, Davis RM, Xu B. Natural product-based nanomedicine: recent advances and issues. Int J Nanomedicine. 2015; 10:6055-6074.
OncoTargets and Therapy

\section{Publish your work in this journal}

OncoTargets and Therapy is an international, peer-reviewed, open access journal focusing on the pathological basis of all cancers, potential targets for therapy and treatment protocols employed to improve the management of cancer patients. The journal also focuses on the impact of management programs and new therapeutic agents and protocols on

\section{Dovepress}

patient perspectives such as quality of life, adherence and satisfaction. The manuscript management system is completely online and includes a very quick and fair peer-review system, which is all easy to use. Visit http://www.dovepress.com/testimonials.php to read real quotes from published authors. 